\title{
Development of Power Operated Pea Sheller
}

\author{
A. S. Waghmode, A. S. Ghadge*, A. B. Ghule, V. Fatale, A. Kolekar and S. Sawashe \\ Department of Farm Machinery and Power Engineering, India \\ *Corresponding author
}

\section{Keywords \\ Bean, Pea depoder, Pea Sheller, \\ Blanching, Roller, Fabrication, Blanched}

\section{Article Info}

Accepted:

20 February 2020 Available Online: 10 March 2020

\section{A B S T R A C T}

Power Operated Pea Sheller machine was developed by us considering the need of rural farmers. There are three types of shelling methods are available such as roller method, tumbler method and shearing method but out of this we selected roller method because it is oldest patented method and the gap between roller can be easily adjusted by screw mechanism. Developed machine is based on the principle of friction generated by the rubbing of pea pods between the two rollers. Machine fabricated by using the low cost material available in market. Test of designed machine carried at initially level and it was observed that at $50 \mathrm{rpm}$ roller speed and clearance between two rollers 2-3 $\mathrm{mm}$ with blanched peas at temp of $98^{\circ} \mathrm{C}$ for time period 1.5 minute was best suited for depoding of peas from pods. The same machine was tested for unbalanced peas and it was observed that $1200 \mathrm{rpm}$ roller speed and gap between two rollers was 3-4 mm best suited having average throughout capacity was $69 \mathrm{~kg} / \mathrm{h}$. Performance evaluation of machine will be done to optimize machine parameters such as peripheral speed of rollers, for blanched and unbalanced peas. Shelled bean weight for blanched peas was $72 \mathrm{~kg} / \mathrm{h}(67.8 \mathrm{~kg}$ whole bean $\& 4.002 \mathrm{~kg}$ damaged pea beans). There was no any part unshelled for blanched peas and damage of pea beans was found $4.002 \mathrm{~kg} / \mathrm{h}$. so for blanched peas shelling efficiency near about $95.8 \%$. While for unblanched peas, shelled bean weight $69 \mathrm{~kg} / \mathrm{h}(64.9 \mathrm{~kg}$ whole pea beans \& $6.64 \mathrm{~kg}$ damaged), $3 \mathrm{~kg} / \mathrm{hr}$ unshelled pea pods were found in power operated pea sheller. So shelling efficiency $90 \%$ for unblanched peas.

\section{Introduction}

Pea is an important leguminous crop sown in rabbi season in India. The commercially grown varieties of peas are - Arkel, Bonneville, Harbhajan, Fc-1, Jawahar Peas 83, Jp 4, Jm 6, Matar Ageta 6, Mithi Phalli, Pantnagar Matar 2 and Golden. In India peas are mainly grown in Uttar Pradesh, Himachal Pradesh, Jharkhand, Madhya Pradesh, Punjab and Uttaranchal. Maharashtra stands the fifth in pea production in India and contributes $3.8 \%$ of the total production of India peas are consumed after removing green kernels from the pods. Depoding of pea grain is based on the principle of friction generated by rubbing action of blades with the pea pods on sieves which helps in opening the pods of peas and cutting action of conveying blades Kamboj et al., (2012). Manual removal of pea kernels 
from pods is a laborious and time consuming job with one person depods about 3 to $3.5 \mathrm{~kg}$ of pea kernels from pods in one hour. It was observed that $60 \mathrm{rpm}$ of blade shaft was best suited for depoding of pea from pods. By using power operated peas sheller, average throughput capacity of the machine was 30 $\mathrm{kg} / \mathrm{h}$. Chris Allen et al., (2012). Today there is large size industrial use machine available but in view of low cost small size efficient domestic machines are currently necessary for small farmers. So we developed Power Operated Pea Sheller machine in Shriram College of Agril. Engg. Paniv, Tal-Malshiras, Dist: Solapur.

\section{Materials and Methods}

\section{Size of pea grains}

Green peas (Pisum sativum) Pea grain size is the geometric mean of the three dimensions i.e. length, breadth, and thickness. The dimensions of peas were measured by using Vernier caliper. Overall size of pea grain was near about $10 \mathrm{~mm}$. The size was calculated using following equation. It is useful for deciding of gap between two rollers which is equals to the size of pea grain.

Size $=(\mathrm{L} \times \mathrm{B} \times \mathrm{T})^{\wedge} 1 / 3$

Where,

$\mathrm{L}=$ length $(\mathrm{mm})$

$\mathrm{B}=$ breadth $(\mathrm{mm})$,

$\mathrm{T}=$ thickness $(\mathrm{mm})$

\section{Size of rollers}

There are various types of rollers available viz. rubber roller, tin sheet, wooden etc. but we were select hollow metal roller due to its light weight. The diameter of roller is $32 \mathrm{~mm}$ and length of roller is $450 \mathrm{~mm}$. The gap between two rollers can be easily adjusted by simple screw mechanism. The gap between these rollers equal to thickness of the pea shell so rollers can be easily pull the pea pods

\section{Size of shaft}

The shaft is made up of M.S bar. in our project we required a two shaft having diameter $10 \mathrm{~mm}$ and length of $600 \mathrm{~mm}$. Shaft used to fitting of roller in bushing $\&$ bearing.

\section{Bearing}

The bearing used to drive the shaft along with roller. The bearing helps to guide the shaft inside it with minimum friction. The bearing size is $12 \mathrm{~mm}$ used in developed pea sheller.

\section{Sprocket}

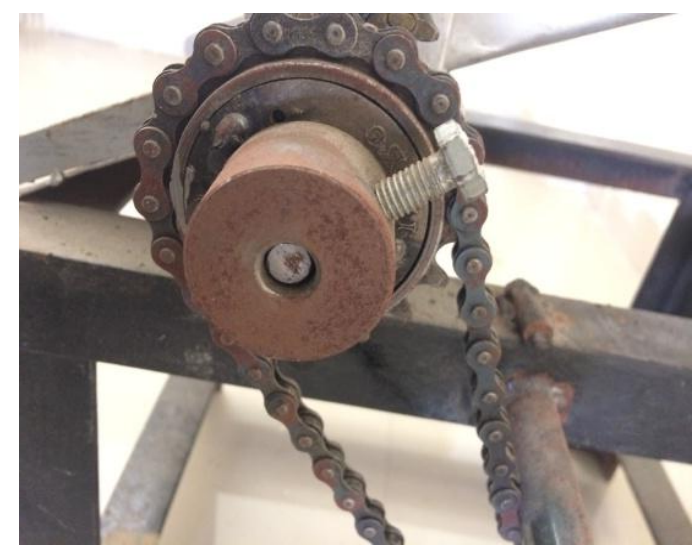

Two sprocket one is driver having size $30 \mathrm{~mm}$ (Dia.) and 12 teeth which is mounted on shaft of motor while another one is driven sprocket having size $60 \mathrm{~mm}$ (Dia.) and no. of teeth 18 mounted on the shaft of roller. These two sprockets driven by chain

\section{Chain}

The chain of length $700 \mathrm{~mm}$ having center distance $180 \mathrm{~mm}$ is used to transmit the power from motor to the roller. The chain having minimum slippage so chain is used in the developed pea shelling machine having chain pitch was $10 \mathrm{~mm}$ 


\section{Specification of chain drive}

1) Type - Roller chain

2) Length $-700 \mathrm{~mm}$

3) Chain pitch $-10 \mathrm{~mm}$

\section{Gears}

The two gears having material cast iron fitted on the shaft of two rollers which gives rotation to both rollers in anticlockwise direction.

The size of gear used is $45 \mathrm{~mm} \&$ no of tooth on each gear are 16 .

\section{Specification of gear drive}

1) Gear Type - Worm gear

2) Gear Size - $45 \mathrm{~mm}$

3) Gear Teeth -16

4) Gear Tooth Thickness - $2 \mathrm{~mm}$

5) Material - Cast Iron

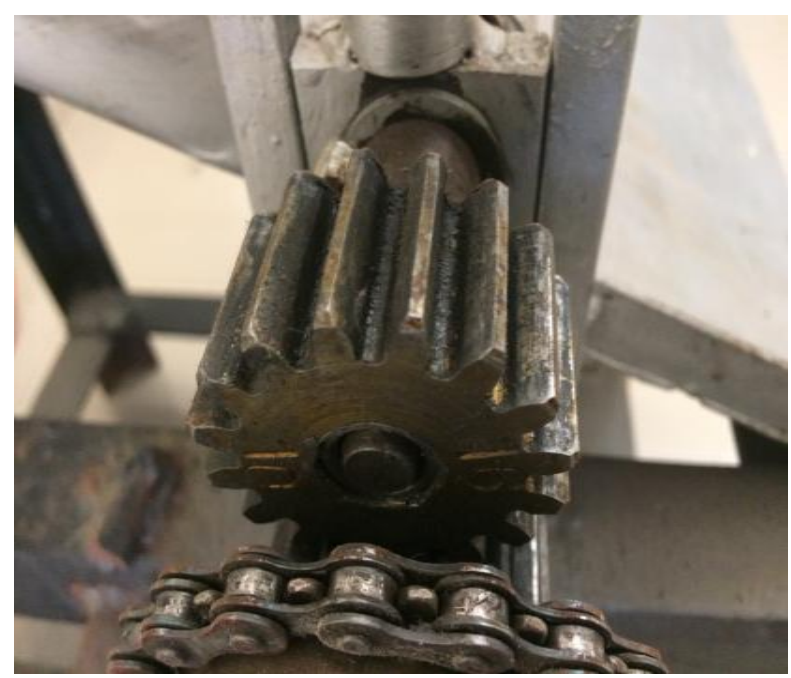

\section{Motor}

Power transmitted to the developed pea sheller by the rollers driven by the $1 / 12 \mathrm{HP}$ universal motor which fitted at bottom of frame with the help the of nut $\&$ bolt. The speed of motor $1500 \mathrm{rpm}$ it can be varying by using dimmer.

\section{Specification of motor}

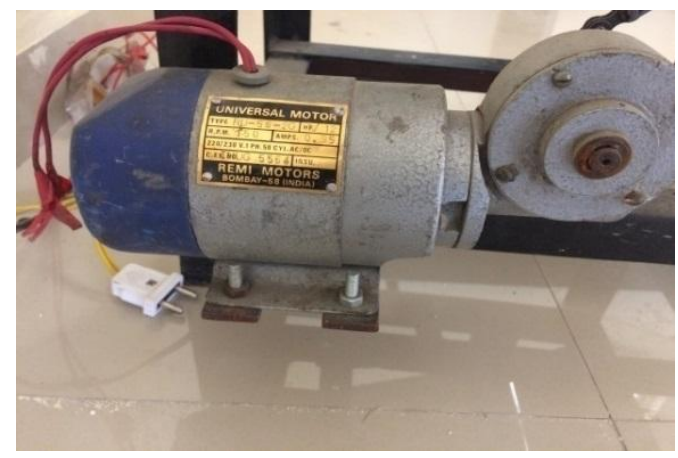

Plate No. 3 single phase A.C electric motor

Type- single phase A.C electric motor Speed - 1500rpm

Power generation - 1/12 hp

\section{Feeding trough}

A Trough which is provided inclination so which pea pods are passed towards the roller and angle of inclination $53^{\circ}$ and capacity of trough $(340 \times 230 \times 50) \mathrm{mm}$.Feeding of pea pods in developed done by manually.

\section{Specification of feed trough}

1) Length $=340 \mathrm{~mm}$

2) Width $=230 \mathrm{~mm}$

3) Thickness $=50 \mathrm{~mm}$

4) Angle of Inclination $=\tan \theta=$ Straight side/ Adjacent side

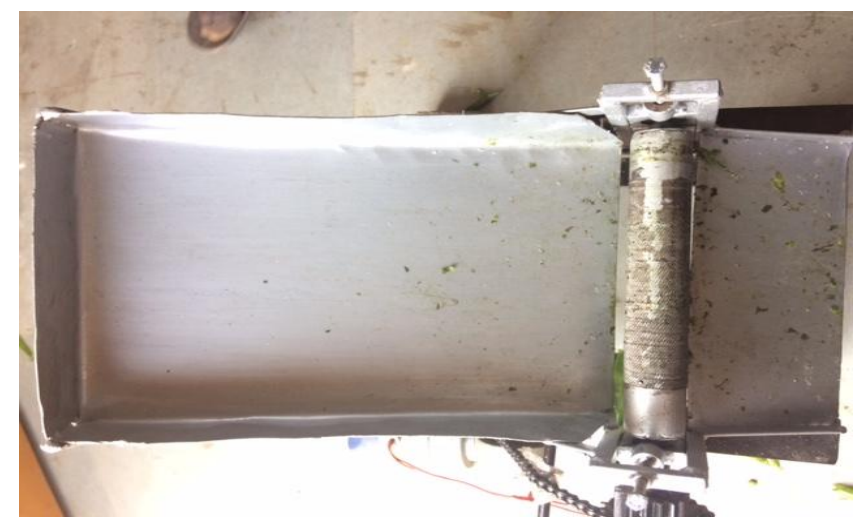

Plate No.4 Feeding Trough 


\section{Angle frame}

The frame made up of M.S. angle. Overall size of machine frame is $(450 \times 300 \times 300)$ $\mathrm{mm}$. This angle joined by weld. The angle iron frame model for these purpose we cut the M.S angle in required dimension of size $(450 \times 300 \times 300) \mathrm{mm}$. This angle cut in required dimension by using cutter then this angle joined together with welding.

Length $=450 \mathrm{~mm}$

Width $=300 \mathrm{~mm}$

Thickness $=300 \mathrm{~mm}$

\section{Methods}

\section{Development of power operated pea sheller}

We fabricate the overall project in collage workshop of Shriram College of Agril. Engg. Paniv.

\section{General specification of machine}

MAKE: Shriram College of Agricultural Engineering, Paniv

MODEL NAME: Power Operated Pea Sheller Machine.

YEAR: 2017-18

\section{Purchased raw material}

1) Angle Frame

2) Roller

3) Feed Trough

4) Sprocket \& Chain

5) Gears

6) Shaft

7) Bearing

8) Motor

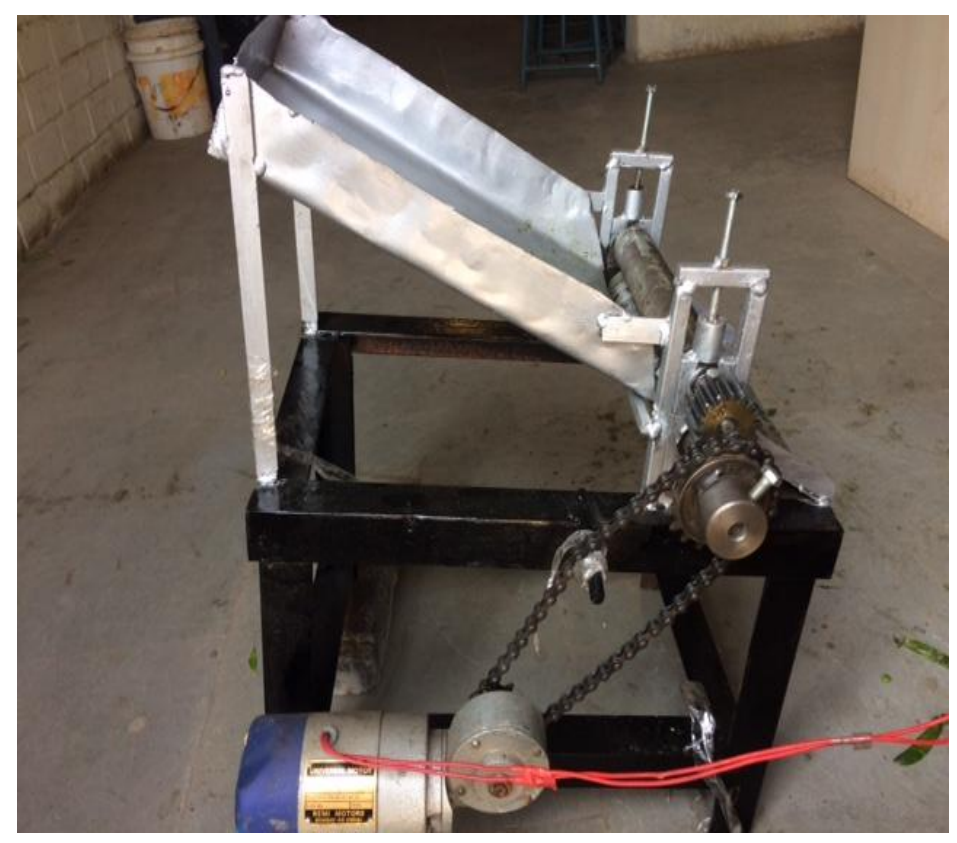

\section{Results and Discussion}

It was observed that 1500 rpm motor speed was best suited for shelling of pea from pods. The capacity of machine was approximate 69 $\mathrm{kg} / \mathrm{hr}$. The shelling efficiency of machine for blanched peas $95.8 \%$ and for unblanched peas $90 \%$ at the motor speed of $1500 \mathrm{rpm}$ and M.C. of $66.6 \%$. So we observed that m.c.\& motor speed both are greatly affects on shelling efficiency of blanched and unblanched peas.

Graph 1 shows that the shelling efficiency of blanched peas at $1200 \mathrm{rpm}$ is more than unblanched peas and its maximum value at m.c $66.6 \%$. Hence we can conclude that shelling efficiency of both blanched and unblanched peas decreases with decreasing of m.c.

Graph 2 shows that the shelling efficiency of blanched peas at $1500 \mathrm{rpm}$ is more than unblanched peas and its maximum value at m.c. $66.6 \%$. Hence we can conclude that shelling efficiency of both blanched and unblanched peas decreases with decreasing of m.c. 
Table.1 Observed efficiency of pea sheller for blanched peas

\begin{tabular}{|c|c|c|c|}
\hline M.C. (\% D.B.) & $\begin{array}{c}\text { Motor Speed } \\
\text { (RPM) }\end{array}$ & $\begin{array}{c}\text { Shelling eff. For } \\
\text { blanched peas (\%) }\end{array}$ & $\begin{array}{c}\text { Damage For } \\
\text { Blanched Peas (\%) }\end{array}$ \\
\hline 66.6 (Fresh) & 1200 & 92.37 & 7.5 \\
& 1500 & 95.8 & 5.8 \\
\hline 60 & 1200 & 90.98 & 9.02 \\
(After1 day) & 1500 & 93.75 & 8.8 \\
\hline 52 & 1200 & 89.73 & 10.8 \\
\hline After 2 days) & 1500 & 91.95 & 9.6 \\
\hline
\end{tabular}

Table.2 Observed efficiency of pea sheller for unbalanced peas

\begin{tabular}{|c|c|c|c|}
\hline M.C. (\% D.B.) & $\begin{array}{c}\text { Motor Speed } \\
\text { (RPM) }\end{array}$ & $\begin{array}{c}\text { Shelling Eff. for } \\
\text { unblanched peas (\%) }\end{array}$ & $\begin{array}{c}\text { Damage For } \\
\text { Unblanched Peas } \\
(\%)\end{array}$ \\
\hline 66.6 (Fresh) & 1500 & 90 & 12 \\
& 1200 & 88.89 & 14 \\
\hline (After1 day) & 1500 & 89 & 13.8 \\
\hline 52 & 1200 & 86.81 & 15 \\
\hline (After 2 days) & 1500 & 88.34 & 21.03 \\
\hline
\end{tabular}

Table.3 Anova table for blanched peas

\begin{tabular}{|c|c|c|c|c|}
\hline Summary & Count & Sum & Average & Variance \\
\hline 66.6 & 2 & 188.17 & 94.085 & 5.88245 \\
\hline 60 & 2 & 184.73 & 92.365 & 3.83645 \\
\hline 52 & 2 & 181.68 & 90.84 & 2.4642 \\
\hline Lseb & 3 & 273.08 & 91.02667 & 1.744033 \\
\hline Useb & 3 & 281.5 & 93.83333 & 3.710833 \\
\hline
\end{tabular}

Anova Table

\begin{tabular}{|c|c|c|c|c|c|c|}
\hline $\begin{array}{c}\text { Source of } \\
\text { Variation }\end{array}$ & $\boldsymbol{S S}$ & $\boldsymbol{d f}$ & $\boldsymbol{M S}$ & $\boldsymbol{F}$ & $\boldsymbol{P}$-value & $\boldsymbol{F}$ crit \\
\hline Rows & 10.5427 & 2 & 5.27135 & 28.72409 & 0.033643 & 19 \\
\hline Columns & 11.81606667 & 1 & 11.81607 & 64.38689 & 0.015178 & 18.51282 \\
\hline Error & 0.367033333 & 2 & 0.183517 & & & \\
\hline Total & 22.7258 & 5 & & & & \\
\hline
\end{tabular}


Table.4 Anova table for unblanched peas

\begin{tabular}{|c|c|c|c|c|}
\hline Summary & Count & Sum & Average & Variance \\
\hline 66.6 & 2 & 178.89 & 89.445 & 0.61605 \\
\hline 60 & 2 & 175.81 & 87.905 & 2.39805 \\
\hline 52 & 2 & 174.18 & 87.09 & 3.125 \\
\hline Lseb & 3 & 261.54 & 87.18 & 2.4283 \\
\hline Useb & 3 & 267.34 & 89.11333333 & 0.698533 \\
\hline
\end{tabular}

Anova Table

\begin{tabular}{|c|c|c|c|c|c|c|}
\hline $\begin{array}{c}\text { Source of } \\
\text { Variation }\end{array}$ & $\boldsymbol{S S}$ & $\boldsymbol{D f}$ & $\boldsymbol{M S}$ & $\boldsymbol{F}$ & $\boldsymbol{P}$-value & $\boldsymbol{F}$ crit \\
\hline Rows & 5.721233333 & 2 & 2.860616667 & 10.74545 & 0.085139 & 19 \\
\hline Columns & 5.606666667 & 1 & 5.606666667 & 21.06054 & 0.044347 & 18.51282 \\
\hline Error & 0.532433333 & 2 & 0.266216667 & & & \\
\hline Total & 11.86033333 & 5 & & & & \\
\hline
\end{tabular}

Graph.1 Shelling efficiency graph for blanched \&Unblanched peas at $1200 \mathrm{rpm}$

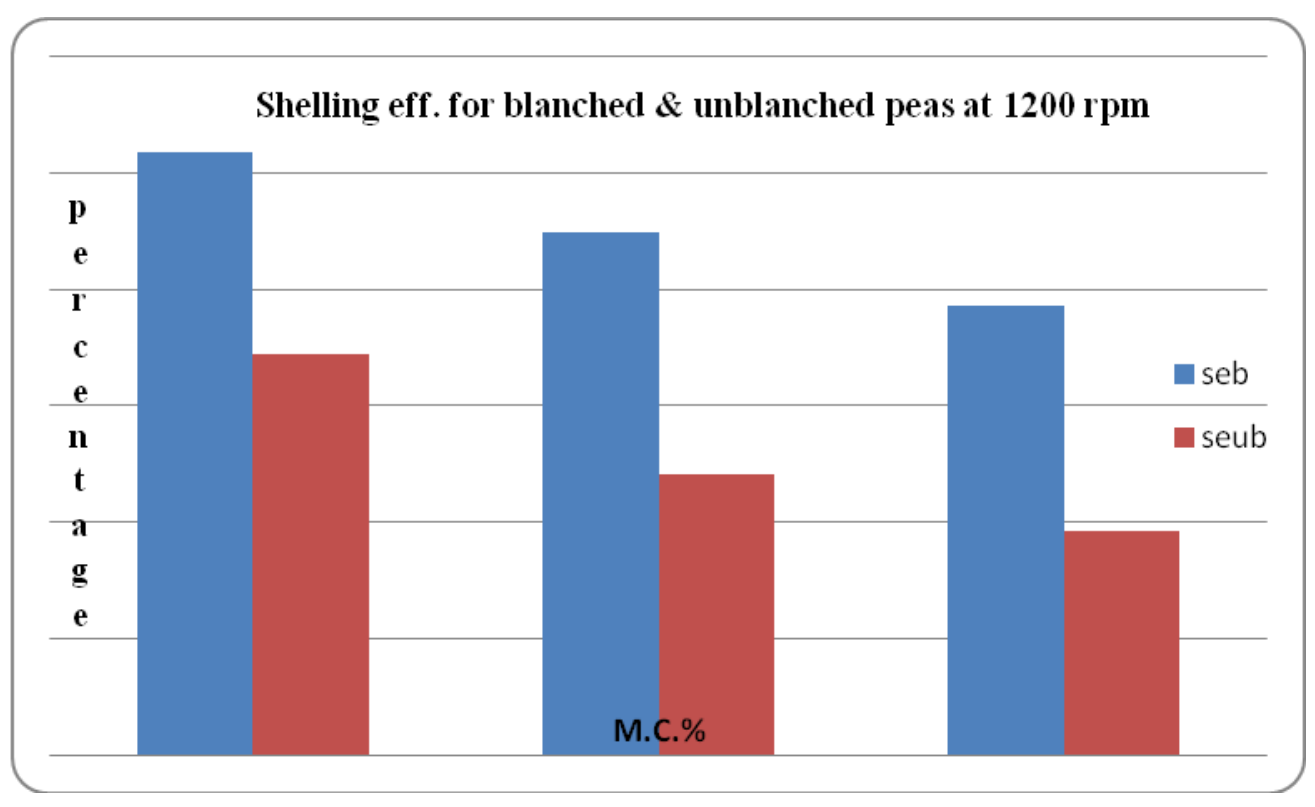


Graph.2 Shelling efficiency graph for blanched \&Unblanched peas at $1500 \mathrm{rpm}$

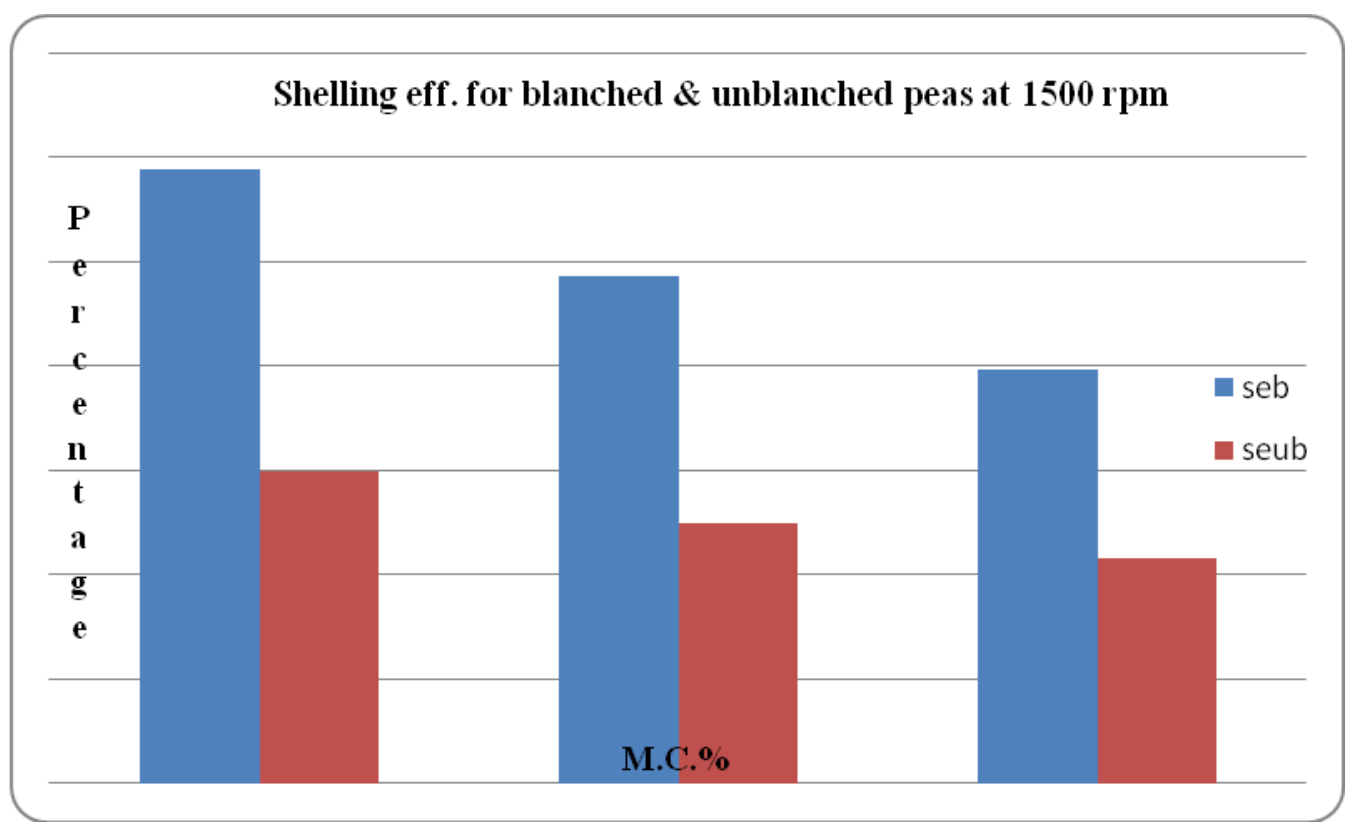

1) From anova table the value of $P$ varies for column as well as row means the value of $P$ varies for m.c and motor speed. but above analysis we observed the value of $\mathrm{P}$ for motor speed is less than the m.c.so motor speed greatly affect the shelling efficiency than m.c. finally we conclude that the value of $\mathrm{P}<0.05$ for coloumn as well as row therefore there is significant difference between m.c and motor speed on shelling efficiency of Unblanched peas.

2) From above anova we seen that variation found for m.c $66.6 \%$ is less than m.c $52 \%$

So shelling efficiency at m.c $66.6 \%$ is more

Hence, concluded in these days, technology has converted hours of work into seconds work. Peas are very popular among people due to its nutritional value. In India and many other countries peas are widely used in dishes during some important occasions such as marriages, functions and parties etc. Manual depoding of peas is a very time consuming task. In view of the non-availability in design and development of a successful pea depoding machine, a power operated pea sheller was undertaken by Shriram College of Agril. Engg. Paniv. Final year students during the period of 2017- 18. The machine is quite simple and is capable to extracting large amount of peas in small time. From analysis, it was observed that capacity of machine was approximate $69 \mathrm{~kg} / \mathrm{hr}$. The shelling Efficiency of machine for blanched peas $95.8 \%$ and for unblanched peas $90 \%$ at the motor speed of $1500 \mathrm{rpm}$ and M.C. of $66.6 \%$. The machine was fabricated by using the low cost material available in local market. This machine will surely help of farmers by adding the value to agricultural products.

\section{References}

Kamboj P. et al., (2012) demonstrated design and development of small scale Pea Depoding Machine by using CAD software

Bo Yuan Lim et al., (2014) development of Jatropha fruit shelling machine

Ikechukwu Celestine Ugwuoke et al., (2014) design and fabrication of a groundnut shelling and separating machine 
powered by electrically

A O Akinyele et al., (2014) development of manual shelling of maize.

Raghtate, Dr. C. C. Handa (2015) study of groundnut Sheller on the shearing action blowering action and separating action.

EnnanuelllesanmiAdeyeye (2015) study of peanut plant is an annual herb belonging to the papilionaceae division of family leguminoceae
A. Mohd Taufik1 and H. Md. Akhir1 (2017) proposed that development of coconut dehusker

Alicia L. Smith et al., (2016) Evaluation of Peanut safety quality for different roasting technologies.

TusharWalke et al., (2017), Design and fabricate a portable groundnut sheller machine for domestic application

\section{How to cite this article:}

Waghmode, A. S., A. S. Ghadge, A. B. Ghule, V. Fatale, A. Kolekar and Sawashe, S. 2020. Development of Power Operated Pea Sheller. Int.J.Curr.Microbiol.App.Sci. 9(03): 2691-2698. doi: https://doi.org/10.20546/ijcmas.2020.903.307. 